\title{
Infantile chronic idiopathic intestinal pseudo- obstruction: the role of small intestinal manometry as a diagnostic tool and prognostic indicator
}

\author{
J M E Fell, V V Smith, P J Milla
}

\begin{abstract}
Background-Chronic idiopathic intestinal pseudo-obstruction (CIIP) presenting in infancy is a rare but serious condition of heterogeneous aetiology often with an uncertain outcome.

Aim-To assess whether intestinal manometry in the first two years of life can help define a neuropathic or myopathic aetiology or clinical outcome, or both, in cases of infantile CIIP.

Subjects and Methods-14 consecutive children who presented in the first year of life with CIIP were studied histologically and by small intestinal manometry.

Results-Five had a myopathic disorder, four were neuropathic, and five unclassified following histological investigation of full thickness intestinal biopsy specimens. Analysis of fasting phase III activity showed four patterns: (1) $(n=4)$ no detectable motor activity, (2) $(n=5)$ low amplitude phase III activity, (3) $(n=3)$ poorly formed phase III complexes of short duration, (4) $(n=2)$ well formed cyclical phase III activity with abnormal propagation. The seven children with low amplitude phase III: motility index (MI) $<10 \mathrm{KPa} / \mathrm{min}$, all had a poor outcome (death or dependence on parenteral nutrition) after 1-10 years follow up, compared with two of seven of those with a MI $>10 \mathrm{KPa} / \mathrm{min}$. Of the five with myopathic histology, four had a $M I<10 \mathrm{KPa} / \mathrm{min}$.

Conclusion-These results show that small intestinal manometry is useful not only as an aid in diagnosing the aetiology of CIIP presenting in infancy, but also in predicting outcome.

(Gut 1996; 39: 306-311)
\end{abstract}

Departments of Gastroenterology and J M E Fell

P J Milla

Histopathology

V V Smith

Great Ormond Street Hospital for Children NHS Trust, Great

Ormond Street,

London

Correspondence to: Dr P J Milla, Institute of Child Health, 30 Guilford Street, London WC1N 1EH.

Accepted for publication 27 March 1996
Keywords: chronic idiopathic intestinal pseudoobstruction, pseudo-obstruction, infantile, manometry, prognosis.

Chronic idiopathic intestinal pseudo-obstruction (CIIP) is a clinical diagnosis of recurrent episodes of intestinal obstruction that are not caused by mechanical occlusion of the bowel. The condition is due to a heterogeneous group of conditions that may primarily or secondarily affect the enteric neuromusculature. In children the conditions are most usually primary disorders of the intrinsic enteric nerves or of the smooth muscle coats, which are congenital in origin and present at birth or during the first year of life. ${ }^{1}$ The clinical diagnosis may be considerably aided by small intestinal manometry in those with diffuse disorders affecting the gut and patterns of motor activity have been described, which some have suggested may be specific to smooth muscle ${ }^{2-5}$ or enteric nerve disease. ${ }^{367}$ Most of the previous assessments have, however, had their difficulties in that either the manometric studies have not been correlated with full thickness biopsy specimens at the site of manometry, or the histopathological analysis has been inadequate.

We have reviewed children with intestinal pseudo-obstruction who had presented in infancy, to assess firstly whether the manometric study of small intestinal motor function performed in the first two years of life provided useful information regarding whether enteric nerves or muscle were affected when matched with histological assessment of full thickness intestinal biopsy specimens subjected to exhaustive and critical examination. Secondly by reviewing the subsequent clinical outcome of patients we have evaluated which manometric features might be useful as a prognostic indicator.

\section{Methods}

\section{PATIENTS}

Fourteen children who had presented to the Hospital for Sick Children in the first year of life from 1983 to 1993 with the presumed diagnosis of chronic idiopathic intestinal pseudo-obstruction (CIIP) were reviewed. Table I gives the clinical details of the patients. All suffered with episodes of functional obstruction and intolerance to enteral feeding. The diagnosis was confirmed by contrast radiography, with subsequent laparotomy at which a stoma was fashioned in all but one case. During the laparotomy full thickness intestinal biopsy specimens were obtained for histological examination. The subjects all underwent small intestinal manometry before the age of two years. Follow up clinical data were available for between 1 and 10 years (median 3 years). None of the patients had evidence of an autonomic nervous system disorder or of a systemic disease that might effect the enteric neuromusculature.

For subsequent analysis the patients were divided into two groups dependent on clinical outcome. A good outcome was defined as 
TABLE I Clinical details of 14 children with CIIP

\begin{tabular}{|c|c|c|c|c|c|c|c|c|c|}
\hline Case & $\operatorname{Sex}$ & $\begin{array}{l}\text { Age at } \\
\text { presentation } \\
\text { (months) }\end{array}$ & $\begin{array}{l}\text { Age when } \\
\text { studied } \\
\text { (months) }\end{array}$ & $\begin{array}{l}\text { Symptoms } \\
\text { at } \\
\text { presentation }\end{array}$ & $\begin{array}{l}\text { Associated } \\
\text { abnormalities }\end{array}$ & $\begin{array}{l}\text { Histological } \\
\text { abnormalities }\end{array}$ & Radiology & Treatment & Outcopme \\
\hline 1 & $\mathrm{~m}$ & 0.07 & 1 & $\begin{array}{l}\text { vomiting } \\
\text { distension }\end{array}$ & $\begin{array}{l}\text { malrotation } \\
\text { bilateral vesico- } \\
\text { ureteric reflux }\end{array}$ & $\begin{array}{l}\text { addtional circular } \\
\text { muscle layer }\end{array}$ & $\begin{array}{l}\text { dilated small } \\
\text { bowel }\end{array}$ & ileostomy & $\begin{array}{l}\text { still TPN } \\
\text { dependent at } \\
1 \text { year }\end{array}$ \\
\hline 2 & $\mathrm{~m}$ & 1 & $1 \cdot 5$ & $\begin{array}{l}\text { vomiting } \\
\text { distension }\end{array}$ & $\begin{array}{l}\text { malrotation } \\
\text { pyloric stenosis }\end{array}$ & $\begin{array}{l}\text { no diagnostic } \\
\text { features }\end{array}$ & $\begin{array}{l}\text { dilated small } \\
\text { bowel }\end{array}$ & $\begin{array}{l}\text { iloostomy } \\
\text { pyloromyotomy }\end{array}$ & $\begin{array}{l}\text { still TPN } \\
\text { dependent at } \\
5 \text { years }\end{array}$ \\
\hline 3 & f & 3 & 22 & $\begin{array}{l}\text { vomiting } \\
\text { constipation }\end{array}$ & $\begin{array}{l}\text { dilated bladder } \\
\text { urinary infections }\end{array}$ & mypopathy & $\begin{array}{l}\text { dilated small and } \\
\text { large bowel }\end{array}$ & $\begin{array}{l}\text { colostomy then } \\
\text { ileostomy }\end{array}$ & $\begin{array}{l}\text { still TPN } \\
\text { dependent at } \\
10 \text { years }\end{array}$ \\
\hline 4 & f & 0.04 & $1 \cdot 5$ & vomiting & $\begin{array}{l}\text { exomphalos, dilated } \\
\text { bladder }\end{array}$ & myopathy & $\begin{array}{l}\text { dilated stomach } \\
\text { and proximal } \\
\text { duodenum }\end{array}$ & ileostomy & $\begin{array}{l}\text { TPN, died at } \\
4 \text { months, } \\
\text { septicaemia }\end{array}$ \\
\hline 5 & f & 0.5 & 1.5 & vomiting & $\begin{array}{l}\text { malrotation } \\
\text { pyloric stenosis } \\
\text { short small intestine }\end{array}$ & $\begin{array}{l}\text { no diagnostic } \\
\text { features }\end{array}$ & malrotation & ileostomy & $\begin{array}{l}\text { TPN, died at } \\
5 \text { months, } \\
\text { septicaemia }\end{array}$ \\
\hline 6 & $\mathrm{~m}$ & $0 \cdot 11$ & 0.5 & vomiting & $\begin{array}{l}\text { malrotation } \\
\text { microcolon, bilateral } \\
\text { hydronephrosis } \\
\text { dilated bladder }\end{array}$ & myopathy & $\begin{array}{l}\text { malrotation } \\
\text { microcolon }\end{array}$ & & $\begin{array}{l}\text { TPN, died at } \\
5 \text { weeks, } \\
\text { septicaemia }\end{array}$ \\
\hline 7 & f & 4 & 11 & $\begin{array}{l}\text { distension } \\
\text { constipation }\end{array}$ & $\begin{array}{l}\text { bilateral hydronephrosis } \\
\text { dilated bladder }\end{array}$ & myopathy & $\begin{array}{l}\text { dilated small and } \\
\text { large bowel }\end{array}$ & ileostomy & $\begin{array}{l}\text { TPN, died at } \\
21 \text { months, } \\
\text { septicaemia }\end{array}$ \\
\hline 8 & f & 0.07 & 22 & vomiting & malrotation & neuropathy & $\begin{array}{l}\text { dilated small } \\
\text { bowel }\end{array}$ & ileostomy & $\begin{array}{l}\text { TPN } 6 \text { months } \\
\text { then enterally } \\
\text { fed for } 2.5 \text { years }\end{array}$ \\
\hline 9 & $\mathrm{~m}$ & 7 & 14 & $\begin{array}{l}\text { constipation } \\
\text { vomiting }\end{array}$ & malrotation, megacystis & myopathy & $\begin{array}{l}\text { dilated small } \\
\text { bowel }\end{array}$ & $\begin{array}{l}\text { ileostomy } \\
\text { gastrostomy }\end{array}$ & $\begin{array}{l}\text { enterally fed at } \\
3 \text { years }\end{array}$ \\
\hline 10 & f & 7 & 10 & $\begin{array}{l}\text { vomiting } \\
\text { distension }\end{array}$ & $\begin{array}{l}\text { familial lower limb } \\
\text { spasticity }\end{array}$ & neuropathy & $\begin{array}{l}\text { dilated small and } \\
\text { large bowel }\end{array}$ & $\begin{array}{l}\text { ileostopmy } \\
\text { cisapride }\end{array}$ & $\begin{array}{l}\text { enterally fed at } \\
4 \text { years }\end{array}$ \\
\hline 11 & $\mathrm{~m}$ & $0 \cdot 25$ & 6 & vomiting & $\begin{array}{l}\text { malrotation } \\
\text { pyloric stenosis } \\
\text { short small intestine, } \\
\text { unilateral } \\
\text { hydronephrosis }\end{array}$ & $\begin{array}{l}\text { addtional circular } \\
\text { muscle layer }\end{array}$ & $\begin{array}{l}\text { dilated small } \\
\text { bowel }\end{array}$ & $\begin{array}{l}\text { Ladd's procedure } \\
\text { pyloromyotomy }\end{array}$ & $\begin{array}{l}\text { enterally fed } \\
\text { postoperatively } \\
\text { died } 5 \text { months }\end{array}$ \\
\hline 12 & f & $0 \cdot 11$ & 4 & vomiting & $\begin{array}{l}\text { polyhydraminios } \\
\text { pyloric stenosis }\end{array}$ & neuropathy & & $\begin{array}{l}\text { ileostomy feeding } \\
\text { gastrostomy }\end{array}$ & $\begin{array}{l}\text { still TPN } \\
\text { dependent at } \\
2.5 \text { years }\end{array}$ \\
\hline 13 & $\mathrm{~m}$ & 4 & 10 & $\begin{array}{l}\text { vomiting } \\
\text { distension }\end{array}$ & $\begin{array}{l}\text { familial lower limb } \\
\text { spasticity }\end{array}$ & neuropathy & $\begin{array}{l}\text { dilated small and } \\
\text { large bowel }\end{array}$ & $\begin{array}{l}\text { ileostomy } \\
\text { cisapride }\end{array}$ & $\begin{array}{l}\text { enterally fed at } \\
4 \text { years }\end{array}$ \\
\hline 14 & $\mathrm{~m}$ & 3 & 12 & distension & $\begin{array}{l}\text { malrotation } \\
\text { pyloric stenosis }\end{array}$ & $\begin{array}{l}\text { no diagnostic } \\
\text { features }\end{array}$ & $\begin{array}{l}\text { slow transit of } \\
\text { barium }\end{array}$ & gastrojejunostomy & $\begin{array}{l}\text { enterally fed at } \\
1 \text { year }\end{array}$ \\
\hline
\end{tabular}

being off parenteral nutrition and tolerating enteral nutrition, whereas a poor outcome was where the patient continued to require parenteral nutrition at follow up (1-10 years: four cases), or died because of a complication of parenteral nutrition (central venous catheter related sepsis in five cases). Those patients treated with prokinetic drugs showed no response to therapy. Control manometric data were obtained from a normative database of seven children we have previously reported (aged 2.9-13 years), 8 who were suspected of having an intestinal dysmotility syndrome but in whom no abnormality of motor activity could be discerned. Three other children aged $0.09,0.63$, and 1.85 years were also studied at the time of duodenal intubation for a small bowel biopsy, where following investigation no intestinal abnormality was found.

\section{SMALL INTESTINAL MANOMETRY}

Motor activity was assessed manometrically after an overnight 15 hour fast as previously described. ${ }^{9}$ A triple lumen manometric catheter with each lumen $0.6 \mathrm{~mm}$ internal diameter and overall diameter of $2.5 \mathrm{~mm}$ and ports at $5 \mathrm{~cm}$ intervals from the distal end, was positioned fluoroscopically with the middle port at the duodenojejunal flexure. Each lumen was perfused with distilled water at 0.4 $\mathrm{ml} / \mathrm{min}$ using a pneumohydraulic infusion apparatus (Arndorfer Medical specialities). Pressure changes were detected by transducers
(Luerlok, Gaeltec, UK) at the proximal end of the manometric tube. Fasting motor activity was recorded for three interdigestive cycles (between four episodes of phase III activity) where this was present, or for four hours, whichever was longer. The manometric patterns were analysed as we have previously described, ${ }^{8}$ by visual planimetry by two independent observers, only one of whom could be blinded to clinical outcome (JF). Because of the extreme variability of phase II activity in CIIP, analysis concentrated on phase III, recognised by its pattern of contractions at 10-14 cycles per minute lasting for greater than one minute. The parameters measured were: mean cycle length of the migrating motor complex as estimated by the time between periods of phase III activity, mean phase III activity duration, mean phase III activity pressure wave frequency, a mean phase III activity motility index (MI) derived from the sum of amplitudes of the contractions per minute, and mean propagation velocity of the phase III activity front. Abnormal contractile activity in phase I and II was also noted. Phase III activity, like the whole migrating motor complex, and its aboral propagation is dependent upon an intact intrinsic neuromusculture and humoral environment, and therefore phase III may conveniently be used as a probe for neuromuscular disease. Because the infants were vomiting and had a severe intolerance to feeds, an assessment of the manometric response to feeds was not undertaken. 
TABLE II Indices of motor function of the small intestine obtained from manometric recordings in 14 children under the age of two with CIIP who had presented in infancy. The controls consist of three normal age matched controls, and seven 'normal subjects' aged 2.9-13 years previously reported by Devane et al ${ }^{8}$

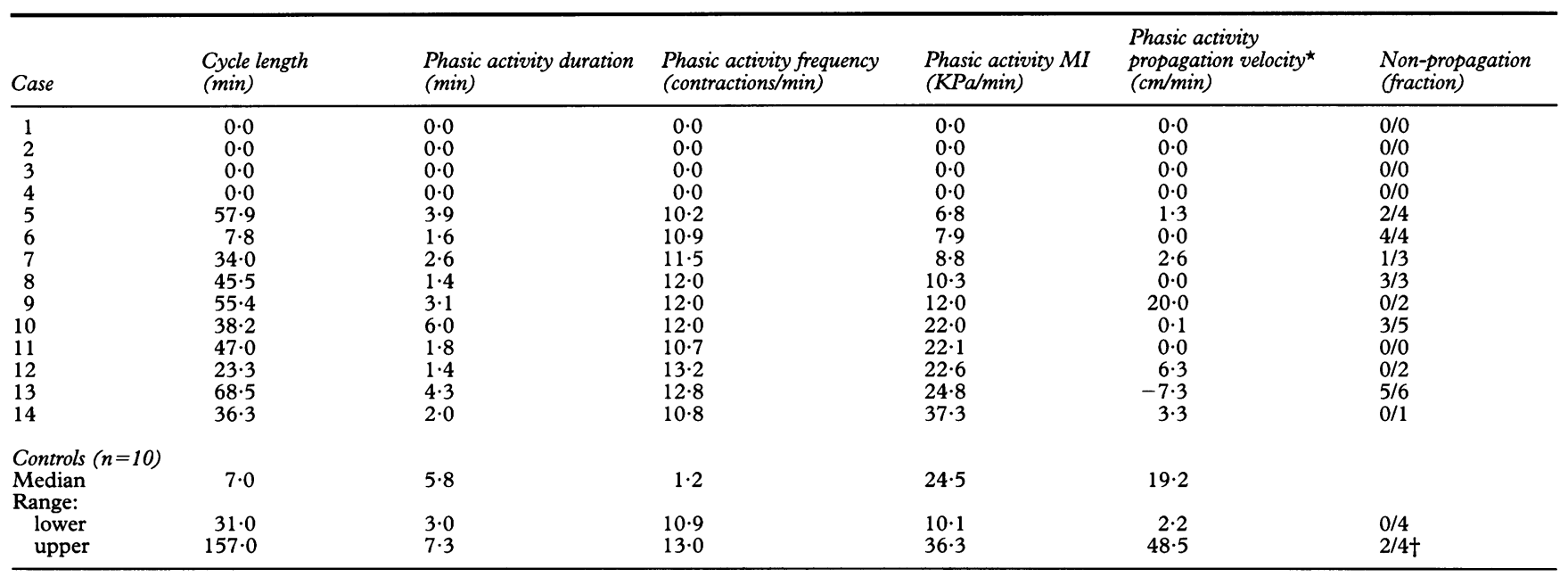

^Negative numbers denote net ad-oral propagation, positive numbers denote ab-oral propagation. $†$ Two infant controls had incomplete propagation.

\section{HISTOLOGY}

\section{Materials}

Fresh full thickness biopsy specimens from proximal and distal small intestine were studied from 13 patients and in addition from four of these, fresh full thickness large bowel biopsy specimens were also examined. From one patient (case 6) only postmortem bowel was available. The samples were divided as follows: a longitudinal full thickness strip was fixed in phosphate buffered formalin for routine histological analysis, a small full thickness strip was fixed in $2.5 \%$ glutaraldehyde in $0.1 \mathrm{M}$ cacodylate buffer at $\mathrm{pH} 7 \cdot 4$ for transmission electron microscopy, and the remainder of the sample was snap frozen in chuck-size full thickness strips for enzyme and immunohistochemical analysis. In addition in seven patients a full thickness piece of intestine measuring $2 \times 2 \mathrm{~cm}$ was fixed flat, mucosa down, pinned on a piece of cork in $10 \%$ formol saline for silver staining.

\section{Study design}

Haematoxylin and eosin stained paraffin wax sections, $3 \mu \mathrm{m}$ thick, were examined for routine morphology and assessment of mysenteric neuronal density. ${ }^{10}$ Cryostat sections of the snap frozen tissue were also stained with haematoxylin and eosin. In addition in cryostat sections the amount of connective tissue was assessed by Gomori trichrome and picrosirius stains, and accumulation of glycogen by periodic acid Schiff after celloidin protection. ${ }^{11}$ The activities of acid phosphatase using the Gomori lead precipitation method and acetyl cholinesterase were also assessed on cryostat sections. ${ }^{11}$ The above methods were performed in each of the 14 patients together with ultrastructural examination. In addition immunostaining ${ }^{1112}$ using the full panel of antibodies to neurofilament triplet protein, neural cell adhesion molecule, muscarinic receptors, contractile proteins (myosin, actins, tropomyosin, filamin, caldesmin), and desmin was performed in nine patients. Morphology of the myenteric plexus was examined by silver staining ${ }^{11} 13$ in seven patients.

\section{STATISTICS}

The motility indices of the two outcome groups were compared using the MannWhitney test.

\section{Results}

\section{MANOMETRY}

Table II summarises the results of the manometric studies from the 14 children with CIIP and controls.

From the patterns of fasting motor activity the children with CIIP could be divided into four groups.

\section{Group 1}

Four patients (1, 2, 3, and 4) had no detectable motor activity during the study period.

\section{Group 2}

Five patients $(5,6,7,8$, and 9$)$ had phase III activity of low amplitude (low motility index) (Fig 1B).

\section{Group 3}

Three patients (11, 12, and 14) had poorly formed phase III complexes of short duration. In phase II there were further short bursts of clustered phasic activity lasting less than one minute (Fig 1C).

\section{Group 4}

Two patients (10 and 13) had well formed cyclical phase III activity, but abnormal propagation (Fig 1D).

Three patients with low amplitude phase III activity (group 2: low motility index), 


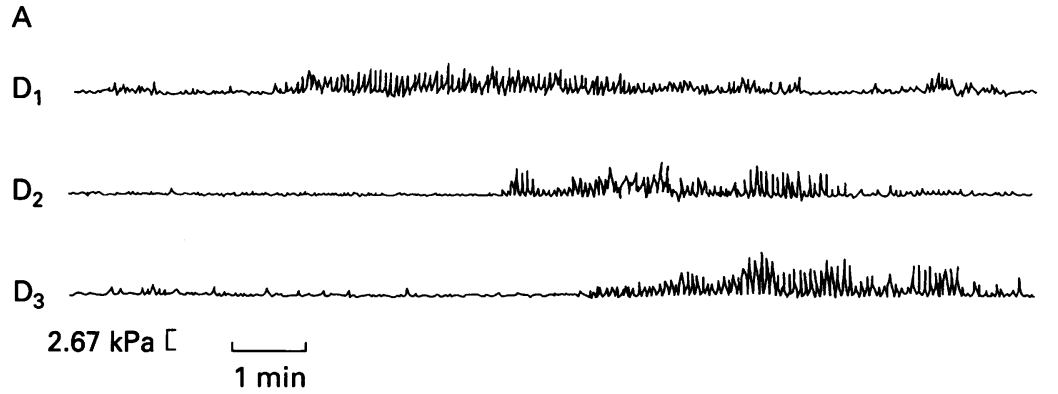

B

$D_{1}$

$\mathrm{D}_{2}$

$D_{3}$

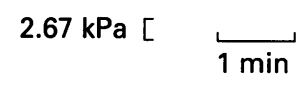

C
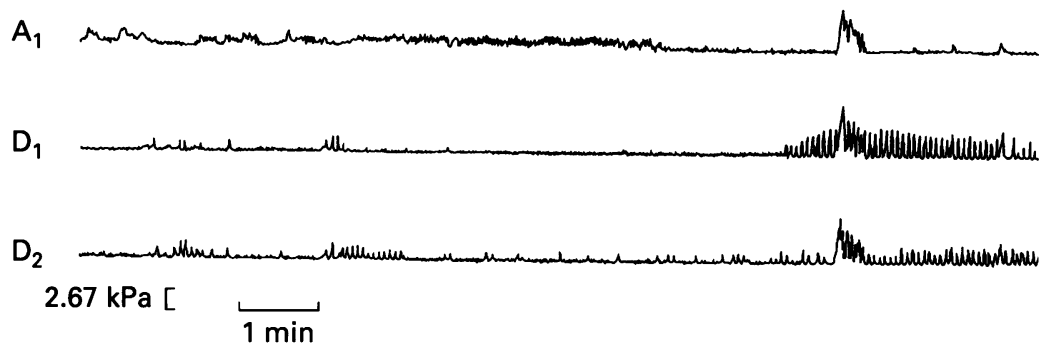

D

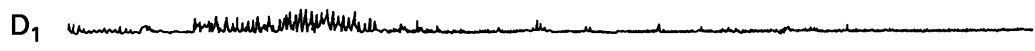

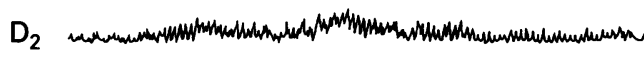

$\mathrm{D}_{3}$

$$
2.67 \mathrm{kPa}[\stackrel{ }{1 \mathrm{~min}}
$$

Figure 1: Fasting motor activity showing typical phase III activity. (A) Normal recording showing well formed phase III complexes with aboral propagation. (B) Group 2, low amplitude (low MI). (C) Group 3, poorly formed phase III complexes of short duration, with short burst of clustered phasic activity in phase II. (D) Group 4, showing well formed phase III activity with abnormal propagation. Ports D1, D2 and D3 are positioned $5 \mathrm{~cm}$ apart in the duodenum. Port $A 1$ is positioned in the antrum.

displayed some of the features of group 3 and 4. Cases 6, 8, and 9 had abnormal propagation, and cases 6 and 8 had phase III activity of only short duration.

Figure 2 shows the relation between motility index and outcome. The poor outcome group (longterm parenteral nutrition, or death complicating parenteral nutrition) as a whole had a significantly lower MI than the good outcome group (fully enterally fed at follow up): (median (range) $6.8 \mathrm{KPa} / \mathrm{mm}(0-22.6)$ verses $22 \mathrm{KPa} / \mathrm{mm}(10 \cdot 3-37 \cdot 7): \mathrm{p}<0.05)$. The absence of detectable motor activity in particular was associated with a poor outcome, while a good outcome was associated with a MI of greater than $10 \mathrm{KPa} / \mathrm{mm}$. Case number 8 with the lowest $\mathrm{MI}$ in the good prognosis group

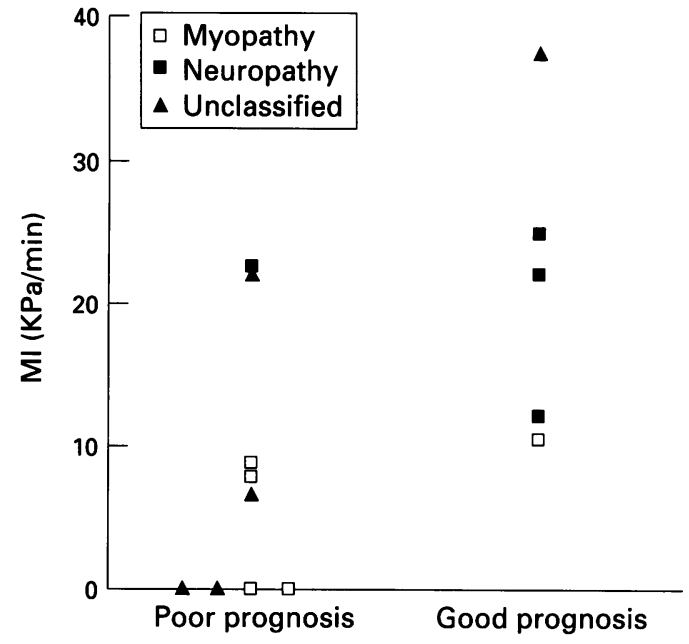

Figure 2: Outcome in relation to $M I$ and pathology for children under the age of two with CIIP. Poor prognosis
defined as death or dependence on parenteral nutrition for defined as death or depend
greater than six months.

$(10.3 \mathrm{KPa} / \mathrm{min})$ required parenteral nutrition for six months after laparotomy before full enteral nutrition was successfully reintroduced.

\section{HISTOLOGY}

Histological evidence of intestinal myopathy comprising fibrosis of varying degree, atrophy, and vacuolation of smooth muscle cells particularly in the circular muscle layer were seen in four patients (case 3, 4, 7, and 9) together with reduced or absent immunostaining for contractile proteins in two of these. In addition increased small tangled neurofilament immunostained nerves, a feature associated with intestinal myopathy, ${ }^{14}$ were noted in the circular muscle of the two patients in whom this investigation was undertaken. Features consistent with myopathy were seen in an additional patient, but the material was obtained at necropsy and it is possible that the changes may have been artefactual (case 6).

Four patients had features of intestinal neuropathy: myenteric hyperganglionosis with distortion of glandular architecture and severe mucosal inflammation (case 12), myenteric hypoganglionosis (case 8), and atrophied and shrunken myenteric neurons (cases 10 and 13). In three patients despite thorough investigation by all the available methods no diagnostic features could be found (cases 2, 5, and 14).

Morphological examination showed in two further patients (half brothers, different father) the myenteric plexus to be embedded within the circular muscle coat resulting in an additional circular muscle layer between the outer and the inner layers of the muscularis propria. No plexus was seen adjacent to the longitudinal muscle. No abnormality was seen on immunostaining or ultrastructural examination (cases 1 and 11).

Of the five cases with a myopathic cause of pseudo-obstruction, four (cases 3, 4, 6, and 7) had a MI less than $10 \mathrm{KPa} / \mathrm{min}$, and had a bad outcome (death or parenteral nutrition dependent). The other case (case 9) had a MI of 12 
$\mathrm{KPa} / \mathrm{min}$, was defined as having a 'good' outcome, but still required parenteral nutrition for six months after surgery.

\section{Discussion}

CIIP most commonly presents in the first year of life, often in the neonatal period, and has a variable outcome. The diagnosis remains a clinical one with recurrent episodes of intestinal obstruction, which for children presenting soon after birth may mean that they have never tolerated enteral feeds at any time. In this clinical setting, small intestinal manometry is an investigative technique that we and others have shown to give information as to the nature of the underlying disorder. ${ }^{2-7}$ This study extends the use of manometry to indicate the severity of the disease process and to provide prognostic information.

Patients with CIIP have, by definition, abnormal intestinal motility. The manometric characterisation of the abnormal motility including adequacy of control data and the analysis of the motility recordings poses several problems. The greatest difficulty is the paucity of adequate age matched normal data for obvious ethical reasons. In this study we have a very small amount of normal data accrued from subjects who were later shown to be of constitutionally short stature, who underwent duodenal intubation as part of their clinical assessment, together with a somewhat larger normative database of children suspected of having malabsorption syndrome who in a hospital setting did not have any discernible gastrointestinal disease or dysmotility symptoms. All of the studies described here were done before the availability to us of miniature strain gauge catheters and digital data collection devices with computerised analytical programmes. Consequently analysis of our data was by visual planimetry, which is time consuming and required verification by a blinded independent observer. Computerised methodologies are however not without their own difficulties and objective meaningful results are dependent upon a carefully devised protocol being rigidly adhered to.

In this study, the histological examination of full thickness biopsy specimens, was used as the 'gold' standard for defining enteric neuromuscular disease. A wide variety of routine methods, histochemical, immunocytochemical, and ultrastructural techniques were used. As a consequence pathological abnormalities were found in nearly all patients studied. These findings while qualitatively similar to a number of previous studies, ${ }^{15-17}$ are quantitatively quite different. In many previous series of patients despite obtaining full thickness biopsy specimens, evidence of abnormality of the enteric nerves or smooth muscle was not obtained. It is particularly true in smooth muscle disease, where if routine staining methods alone are relied on, abnormality is only detected in $50 \%$ of patients. Immunocytochemistry is required to detect congenital defects of myocyte contractile proteins, ${ }^{12}$ and electron microscopy for a variety of degenera- tive disorders. ${ }^{15}$ However this study shows that small intestinal manometry in this group of patients can predict the presence of smooth muscle disease and can thus alert the histopathologist to this possibility, thus ensuring the optimal use of the limited material available.

From manometric studies in those children with muscle disease the amplitude of contractile activity and the MI was low compared with both controls and with the neuropathic group as has been previously reported. ${ }^{14}$ As might be expected the force of contraction was considerably reduced in all patients, but in some the organisation of the cyclical fasting complex was still discernible, with sequentially propagated phase III activity despite the reduced phase III contractions. Thus in these patients the episodes of obstruction are due to ineffectually contracting smooth muscle in the abnormal smooth muscle coats. In contrast, in those with intrinsic neuropathic disorders, there was either no contractile activity or the contractions were of normal amplitude with a normal to increased MI but with disturbed organisation of the cyclical pattern of interdigestive activity and abnormal propagation of phase III activity. In cases 11,12 , and 14 the phasic activity recorded was reminiscent of that seen in premature infants at the stage of clustered phasic development of fasting motor activity. ${ }^{18}$ In such infants transit of gut contents and tolerance to oral feeds is associated with the degree of propagation of clustered activity. 19 Two of three patients (cases 12 and 14) who had a good outcome had a high proportion of aborally propagated phasic activity.

The specificity of the manometric abnormalities found particularly in the neuropathic group is open to question as others have identified 'neuropathic' manometric abnormalities in infants who were being investigated for diarrhoeal symptoms, which subsequently proved to be secondary to coeliac disease ${ }^{20}$ and other mucosal enteropathic processes (Milla PJ, unpublished data). These findings suggest that the so called 'neuropathic' abnormality does not necessarily represent a histological abnormality, but may result from either nerves and muscle being involved in the inflammatory process causing the enteropathy, or by the effect of particular inflammatory mediators and metabolites affecting enteric neuromuscular function. The degree of uncertainty surrounding the interpretation of the manometric 'neuropathic' abnormalities is further heightened in the light of observations that showed that delayed introduction of enteral nutrition to premature infants results in a delay in the maturation of motor activity. ${ }^{19} 21$ In our study many of the subjects, because of the very nature and severity of their disease, had never been enterally fed by the time they were investigated. This factor by itself may influence the intestinal motor activity measured. Thus the specificity of manometric abnormality to a neuropathic disease process seems less secure than hitherto thought, and caution should be exercised in ascribing intrinsic neuropathic disease to a particular manometric pattern. We have as yet, however, not observed the low 
MI (low amplitude phase III activity) pattern, seen in our patients with undoubted muscle disease, in other disease processes. These difficulties with respect to neuropathic motor abnormalities should therefore not detract from the value of small intestinal manometry as a tool for the diagnosis of the myopathic patient and in the assessment of prognosis shown by this study. It seems clear from our study that small intestinal motor activity with a low MI (low amplitude phase III activity) in the first two years of life, in a patient presenting in infancy with CIIP, is associated with a poor outcome in terms of survival or the need for longterm parenteral nutritional support.

1 Milla PJ, Smith VV. Intestinal neuronal dysplasia. 7 Pediatr Gastroenter Nutr 1993; 17: 356-7.

2 Milla PJ, Lake BD, Spitz L, Nixon HH, Harries JT, Fenton TJ. Chronic idiopathic intestinal pseudo-obstruction of infancy. In: Labo G, Bortolotti M, eds. Gastrointestinal motility. Verona: Cortina International, 1983: 125-31.

3 Wozniak EDR, Fenton TR, Milla PJ. Fasting small intestinal motor activity in chronic idiopathic intestinal pseudoobstruction CIIP. [Abstract.] Pediatr Res 1984; 18: 1060 .

4 Anuras S, Anuras J, Bozeman T. Small intestinal manometric studies in patients with familial visceral myopathies. $\mathcal{f}$ ric studies in patients with familial

5 Tomomasa T, Itoh Z, Kitamura T, Suzuki N, Matsuyama $S$, Kuroume T. Manometric study on the intestinal motility in a case of megacystis-microcolon-intestinal hypoperistalsis syndrome. I Pediatr Gastroenter Nutr 1985; 4: 307-10.

6 Stanghellini V, Camilleri M, Malagelada J-R. Chronic idiopathic intestinal pseudo-obstruction: clinical and intestinal manometric findings. Gut 1987; 28: 5-12.

7 Hyman PE, McDiarmid SV, Napolitano J, Abrams CE, Tomomasa T. Antroduodenal motility in children with chronic intestinal pseudo-obstruction. $f$ Pediatr 1988; 112: 899-905.

8 Devane SP, Coombs R, Smith VV, Bisset WM, Booth IW, Lake BD, et al. Persistent gastrointestinal symptoms after correction of malrotation. Arch Dis Child 1992; 67: 218-21.

9 Fenton TR, Harries JL, Milla PJ. Disordered small intestinal motility: a rational basis for toddler's diarrhoea. Gut 1983; 24: 897-903.

10 Smith VV. Intestinal neuronal density in childhood: a baseline for the objective assessment of hypo- and hyperganline for the objective assessment of hypo-
glionosis. Pediatr Pathol 1993; 13: 225-37.

11 Filipe IM, Lake BD. Histochemistry in pathology. 2nd ed. Edinburgh: Churchill Livingston, 1990: 444-64.

12 Smith VV, Lake BD, Kamm MA, Nicholls JR. Intestinal pseudoobstruction with deficient smooth muscle alpha actin. Histopathology 1992; 21: 535-42.

13 Smith VV, Lake BD. Pathology of intestinal pseudoobstruction. In: Kamm MA, Leonard-Jones JE, eds. Constipation. Petersfield: Wrightson Biomedical, 1994: 241-50.

14 Smith VV. Neurofilament antibodies will differentiate muscle and nerve disorders of chronic idiopathic intestinal pseudoobstruction. Proc R Micr Soc 1990; 25: 52.

15 Krishnamurthy S, Schuffler MD. Pathology of neuromuscular disorders of the small intestine and colon. cular disorders of the small
Gastroenterology 1987; 93: $610-39$.

16 Vargas JH, Sachs P, Ament ME. Chronic intestinal pseudoobstruction in pediatrics. $\mathcal{F}$ Pediatr Gastroenterol Nutr 1988; 7: 323-32.

17 Navarro J, Gonsino E, Boige N, Nabarra B, Ferkadji L, Mashako LMN, et al. Visceral neuropathies reversible for chronic intestinal pseudo-obstruction syndrome in pediatric practice. $\mathcal{F}$ Pediatr Gastroenterol Nutr 1990; 11: 179-95.

18 Bisset WM, Watt J, Rivers RPA, Milla PJ. Postprandial motor response of small intestine to enteral feeds in motor response of small intestine to enteral feeds

19 Berseth CL. Effect of early feeding on maturation of the preterm infant's small intestine. F Pediatr 1992; 120: pretrin in

20 Cucchiara S, Bassotti G, Castellucci G, Minella R, Betti C, Campanozzi A, et al. Abnormalities of small intestinal motility in children with active coeliac disease. $\mathcal{F}$ Pediatr Gastroenterol Nutr 1993; 17: 469.

21 Bisset WM, Watt J, Rivers RPA, Milla PJ. Postprandial motor response of the small intestine to enteral feeds in preterm infants. Arch Dis Child 1989; 64: 1356-61. 